\title{
Features of gold-bearing quartz veins in an artisanal mining- dominated terrain, Batouri gold district, Eastern region of Cameroon
}

\author{
${ }^{1}$ Department of Civil Engineering, The University Institute of Technology (IUT), University of Douala, P.O. Box 8698, Douala, Cameroon; \\ *Corresponding author, E-mail:vakumbom@gmail.com \\ ${ }^{2}$ Laboratory of Geosciences Natural Resources and Environment, Department of Earth Sciences, Faculty of Science, University of Douala, \\ P.O. Box 24157, Douala, Cameroon \\ ${ }^{3}$ Economic Geology Unit, Department of Geology, University of Buea, P.O. Box 63, Buea, Cameroon \\ ${ }^{4}$ Department of Geology, Mining and Environmental Science, Faculty of Science, University of Bamenda, P.O. Box 39, Bambili, Cameroon \\ "This contribution is part of the study funded by the International Union of Geological Science (IUGS) under its "Resourcing Future Generations" \\ programme Coordinated at the University of Buea by CES
}

(Received: July 6, 2018; Revised accepted: June 15, 2019)

https://doi.org/10.18814/epiiugs/2019/019016

In a bid to identify features useful in discriminating barren from gold-bearing veins and thus assist in the training of locals on site suitability selection for shallow-depth gold exploitation from weathered veins, we investigated a major vein set in the Batouri gold district of eastern Cameroon hereafter referred to as the Mama vein system. The mineralized veins trend $N E-S W$ and are foliated with sericitic, carbonate, sulphides and hematitic alterations. Quartz in the mineralized veins is brecciated, fibrous and smoky. Gold grains occur as inclusions in hematite mainly derived from the weathering of sulphides. Thus brecciated to stock work hematite-bearing veins in prospective mining sites is the main target for the local miners since they are the main host of primary mineralization in Batouri. The gold grains are rich in $\mathrm{Ag}$ and show low gold fineness (maximum 615). Bulk geochemistry reveals $\mathrm{Au}-\mathrm{As}-\mathrm{Hg}-\mathrm{Zn}-\mathrm{Pb}-$ Sb-Mo element association indicative of a low sulphidation environment. Fluid inclusion data affirm to moderate salinity brine as the ore-bearing fluids and mesothermal conditions of ore deposition consistent with the magmatic source of gold. The $\delta^{34} S$ values for this system reflect a single homogenous and general light source for sulfur.

\section{Introduction}

In many parts of Africa small scale mining activities are carried out by local people using very rudimentary tools. Increasingly administrative authorities, in a bid to improve quality of life in such communities and also derive state revenue from their activities, are requiring the artisanal miners to comply with various administrative procedures. However, these persons lack the technical know-how as is the case in the Batouri gold district of eastern Cameroon (Fig. 1). Consequently within the International Union of Geological Science (IUGS) framework "Resourcing Future Generations" we put in an application for IUGS funding to train miners in the Batouri area on basic map reading techniques and recognition of prospective mining areas through GIS-generated maps. This is the initial contribution from this project. Here we provide the characteristics of quartz vein being exploited by the locals and use its features as the basis of guiding them on selecting similar prospective sites. However, considering that this is a scientific communication we also provide more data on this vein system for a wider comprehension of the nature of vein-related mineralization in the area.

Primary mineralization within the Central Cameroon Shear Zone (CCSZ) system is hosted by quartz \pm carbonate veins (Suh et al., 2006; Asaah et al., 2014; Vishiti et al., 2015). These auriferous qurtz veins show evidence of brittle/ductile deformation (Vishiti et al., 2017). Although lode gold mineralization in the Bétaré Oya area has been chareacterized (Vishiti et al., 2017), as well as gold grains recovered from exploration pits in the Batouri gold mining area (Vishiti et al., 2015), the trace element signature of sulphides and gold microchemical signature of the auriferous veins are still poorly constrained. Also, fluid inclusion studies widely used in mineral exploration and metallogenetic studies (Ulrich et al., 1999; Wilkinson, 2001; Yudovskaya et al., 2006; Suh, 2008; Zoheir et al., 2008; Soloviev et al., 2013) have not been completed on the Mama vein system. Furthermore, although $\delta^{34} \mathrm{~S}$ isotope data has been reported in the Bétaré Oya gold mining district of eastern Cameroon (Vishiti et al., 2017), the $\delta^{34} \mathrm{~S}$ isotopic signature of sulphides in Batouri is not known. All these data sets are relevant in developing exploration predictive models in the Batouri area.

Here we present the textural, geochemical and fluid inclusion characteristics of the mineralized veins and discuss their usefulness in prospection. We also present sulfur isotope data for the system more 


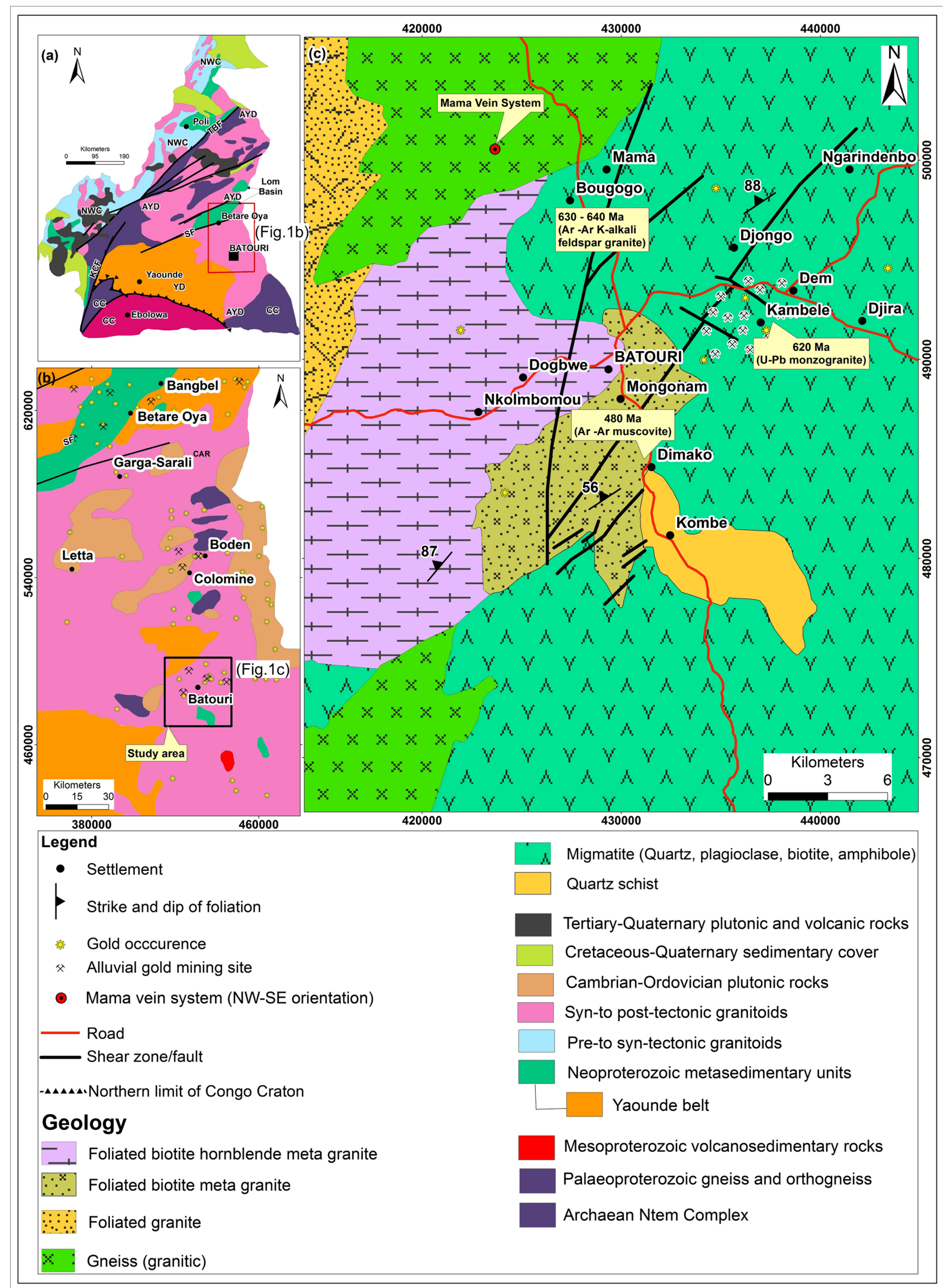

Figure 1. (a) Map of Cameroon locating the study area Batouri in the eastern region of Cameroon (red rectangle not to scale). (b) Map of the eastern region of Cameroon showing the distribution of Au occurrences. Note the concentration of gold in the eastern region of Cameroon (black rectangle not to scale). (c) Geologic map (modified after Suh and Lehmann 2003; Suh et al., 2006) of Batouri with the main structural and lithologic units. The square box defines the Mama vein system. The World Geodetic System 1984, Universal Transverse Mercator Zone $33 N$ coordinate was used. 
for the purposes of a better scientific understanding of this auriferous system.

\section{Location, Regional and Deposit Geology}

The Batouri gold mining area in southeastern Cameroon belongs to the Adamawa Yade domain (Fig. 1a) of the Central African fold belt (Pan African; Toteu et al., 2004; Van Schmus et al., 2008; Kouske et al., 2012; Asaah et al., 2014). The evolution of the Central African Fold belt can be attributed to the convergence and collision between the São Francisco-Congo Craton and the West African Craton (WAC) and a Pan African Mobile belt (Castaing et al., 1994). It underlies Cameroon, Chad and the Central African Republic, between the Congo Craton to the south and the Western Nigeria shield to the north (Van Schmus et al., 2008; Li et al., 2017). The Adamawa Yade Domain extends eastwards from Cameroon into the Central African Republic where it is known as the Yade massifs (Van Schmus et al., 2008) and is bounded to the north by the Tcholliré-Banyo fault and to the south by the Yaoundé Domain. The Adamawa Yade domain is underlain by a variety of granitic rocks including alkali-feldspar, granite, quartz alkali granitoids, syeno-monzogranite, granodiorites, diorites and tonalite (Asaah et al., 2014; Tata et al., 2018). The granites are Pan African, metaluminous, I-type granites. Biotite-gneiss xenoliths are ubiquitous in most rocks occurring in the area. These enclaves are believed to represent fragments of the underlying Palaeoproterozoic-Archaean basement rocks or Neoproterozoic high-grade metasedimentary rocks (e.g. Toteu et al., 1994, 2004, 2006; Van Schmus et al., 2008).

In the Batouri area, gold is hosted by hydrothermally altered granitoids with concentrations reaching a high of 103.7 ppm (Tata et al., 2018). Gold mineralization is accompanied by sericitization, silicification and sulphidation/ferruginization. The granitoids represent part of regional scale batholiths with small-scale, high-grade auriferous quartz veins in structurally favorable sites (Asaah et al., 2014). The quartz veins are defined by NE-SW-trending shear zone which forms part of the Central Cameroon Shear Zone system (Suh et al., 2006). This shear zone is a Pre-Mesozoic crustal strike- slip fault system that extends from central Africa, across the Atlantic into NE Brazil (Toteu et al., 2004; Neto et al., 2008). The tectonic evolution of the Pan-African belt in central and southern Cameroon resulted in structures including a $\mathrm{N} 70^{\circ} \mathrm{E}$ sinistral shear zone of central Cameroon (Central Cameroon Shear Zone (CCSZ)) to the north and Sanaga fault (SF) to the south (Ngako et al., 2003; Fig. 1). The gold bearing quartz veins are enclosed by hydrothermally altered zones traceable into the wall rock (Suh and Lehmann, 2003; Suh et al., 2006; Suh, 2008; Asaah et al., 2014) as well as in the soils (Vishiti et al., 2015). The mineralized quartz veins are ferruginized and sulfidized. Consequently albite, sericite, silica, chlorite, epidote, calcite, hematite and pyrite appear in the foliated altered rock. Gold in this area is mined by artisanal methods from primary pyrite-bearing quartz veins, eluvial and alluvial workings (Fig. 1b). Alluvial Au exploitation strictly follows current river channels. The Batouri gold mining area is underlain by variably deformed deeply weathered granitic rocks (Fig. 1c).

\section{Quartz Vein Characterization: Structure, Texture, Mineral Microchemistry, Trace Element Geochem- istry, Fluid Inclusion and Sulfur Isotope Analysis}

Initial field visit to Batouri was made to create contacts with the administrative authorities where they were briefed on the mission. Contacts were created with local mining communities and also local authorities. Interactions with artisans were made in the field where they were educated on how to use the features of quartz veins to select suitable sites for artisanal mining.

The quartz vein system was mapped and collected samples polished and studied under reflected and transmitted light, while the composition of various mineral phases was determined using electron microprobe. The major and trace element composition of pyrite and gold grains were obtained quantitatively by wavelength dispersive spectrometry (WDS) using a JEOL SUPERPROBE 8200 analyzer at GEOMAR, Kiel. In order to achieve surface conductivity, representative polished sections were coated with carbon film prior to the EMPA analysis. During EMP-analysis, care was taken to select analytical points free from cracks.

Pyrite in quartz vein samples from the Mama quartz vein systems was analyzed for $\mathrm{Sn}, \mathrm{As}, \mathrm{S}, \mathrm{Cu}, \mathrm{Cd}, \mathrm{Se}, \mathrm{Hg}, \mathrm{Fe}, \mathrm{Ag}, \mathrm{Au}, \mathrm{Sb}$, and $\mathrm{Zn}$ using a $1 \mu \mathrm{m}$ beam at $15 \mathrm{kV}$ accelerating voltage and $50 \mathrm{nA}$ beam current. In order to improve the statistics of the count rates, counting times were $60 \mathrm{~s}$ for $\mathrm{Sn}, \mathrm{Hg}, 40 \mathrm{~s}$ for $\mathrm{As}, 30 \mathrm{~s}$ for $\mathrm{S}, \mathrm{Sb}$ and $20 \mathrm{~s}$ for $\mathrm{Cu}$, $\mathrm{Cd}, \mathrm{Se}, \mathrm{Fe}, \mathrm{Ag}, \mathrm{Au}, \mathrm{Zn}$. Standard specimens used for calibration were: cassiterite ( $\mathrm{Sn}$ ), GaAs (As), chalcopyrite (for $\mathrm{Fe}, \mathrm{S}, \mathrm{Cu}$ ), $\mathrm{CdS}$ (for $\mathrm{Cd}$ ), $\mathrm{Bi}_{2} \mathrm{Se}_{3}$ (for $\mathrm{Se}$ ), $\mathrm{HgS}$ (for $\mathrm{Hg}$ ), AgTe (for $\mathrm{Ag}$ ) $\mathrm{Au} 100$ (for $\mathrm{Au}$ ), $\mathrm{InSb}$ (for $\mathrm{Sb}$ ), and sphalerite (for $\mathrm{Zn}$ ). A chalcopyrite standard was run after every 10 analyses to ensure quality control on the data.

Identified gold grains within the samples were analyzed for $\mathrm{Au}$, Ag, As and $\mathrm{Hg}$ using a $1 \mu \mathrm{m}$ beam at $15 \mathrm{kV}$ accelerating voltage and $50 \mathrm{nA}$ beam current. Counting times were $20 \mathrm{~s}$ for $\mathrm{Ag}, \mathrm{Au}, 40 \mathrm{~s}$ for As and $60 \mathrm{~s}$ for $\mathrm{Hg}$. Standard specimens used for calibration were $\mathrm{Au}_{80} \mathrm{Ag}_{20}$ (for $\mathrm{Au}, \mathrm{Ag}$ ), GaAs (for $\mathrm{As}$ ) and $\mathrm{HgS}$ (for $\mathrm{Hg}$ ). The $\mathrm{Au}_{80} \mathrm{Ag}_{20}$ standard was run after every 5 analyses and Au fineness was calculated using the formula $\mathrm{Au}^{*} 1000 / \mathrm{Au}+\mathrm{Ag}$ (Hallbauer and Utter, 1977).

The quartz vein samples were also analyzed for whole rock composition. Selected trace elements were analyzed for using a combination of instrumental neutron activation analysis (INAA) and inductively coupled plasma mass spectrometry (ICP-MS) following a lithium metaborate/tetraborate fusion and dilute nitric digestion at Acme and Activation Labs., Ltd (Canada). Duplicates were fused and analyzed after every 15 samples, and the instrument was recalibrated after every 40 samples. Fusion ensures that also the highly refractive REE and HFSE are dissolved. Loss on ignition was determined by weight difference after ignition at $1000^{\circ} \mathrm{C}$. The detection limits and quality assurance indicators are available at www.acmelabs.com and www.actlabs.com.

For the fluid inclusion studies, doubly polished sections were prepared for each sample. These sections were reduced to wafers $\sim 33 \mu \mathrm{m}$ thick, mounted on glass slides, and the nature of the fluid inclusions in them studied under a high magnification transmitted light petrographic microscope. To liberate the wafer from the glass slide, each slide was immersed in acetone for about 10 minutes to dissolve the 
Canada balsam glue and subsequently rinsed with distilled water several times. Inclusion of interest were then analyzed for their microthermometric data using a United States Geological Survey-type heating freezing stage (Roedder, 1984) in the microthermometric laboratory in GEOMAR, Kiel. This stage consists of a high resolution microscope that is equipped with a heating device and connected to a liquid nitrogen tank by a tiny tube. During the freezing runs, liquid nitrogen is passed over the quartz wafer slowly until the inclusion freezes completely (at $\sim-100^{\circ} \mathrm{C}$ ). The frozen inclusion is subsequently heated up at a rate of about $0.1^{\circ} \mathrm{C} /$ second until the ice starts melting. This initial ice melting temperature (Tm) is noted. Heating continued until the vapour and liquid phases of the inclusions homogenized into a single phase (usually into the liquid phase), and the meniscus between then disappeared. This is known as the total homogenization temperature, Th.
Samples for S-isotope analysis were prepared by drilling with a Proxxon Minimot 40/E hand drill to obtain a fine powder at the Hydrothermal Laboratory in GEOMAR, Kiel. About $0.8 \mathrm{~g}$ of sulphur concentrate from each sample was bottled for sulphur isotope analysis. $\delta^{34} \mathrm{~S}$ data of sulphide minerals were determined at the Institut für Geologie und Paläontologie, Westfälische Wilhelms-Universität Münster, Germany, using a Thermo Finnigan Delta Plus mass spectrometer coupled with an elemental analyser (Carlo Erba).

\section{Vein Structure}

Two main types of quartz veins were observed within the Mama auriferous vein system: mineralized and barren quartz veins. The veins cut through a granitic host rock and are oriented NE-SW. Within the vein system granitic wall rock selvages are common (Fig. 2). The
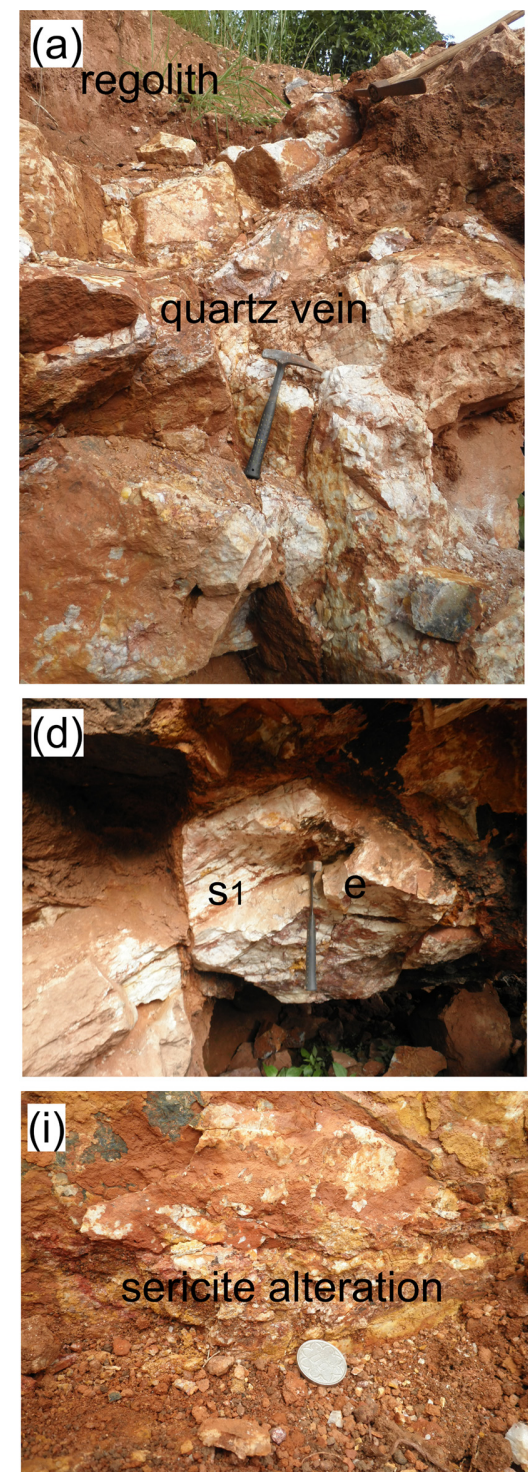
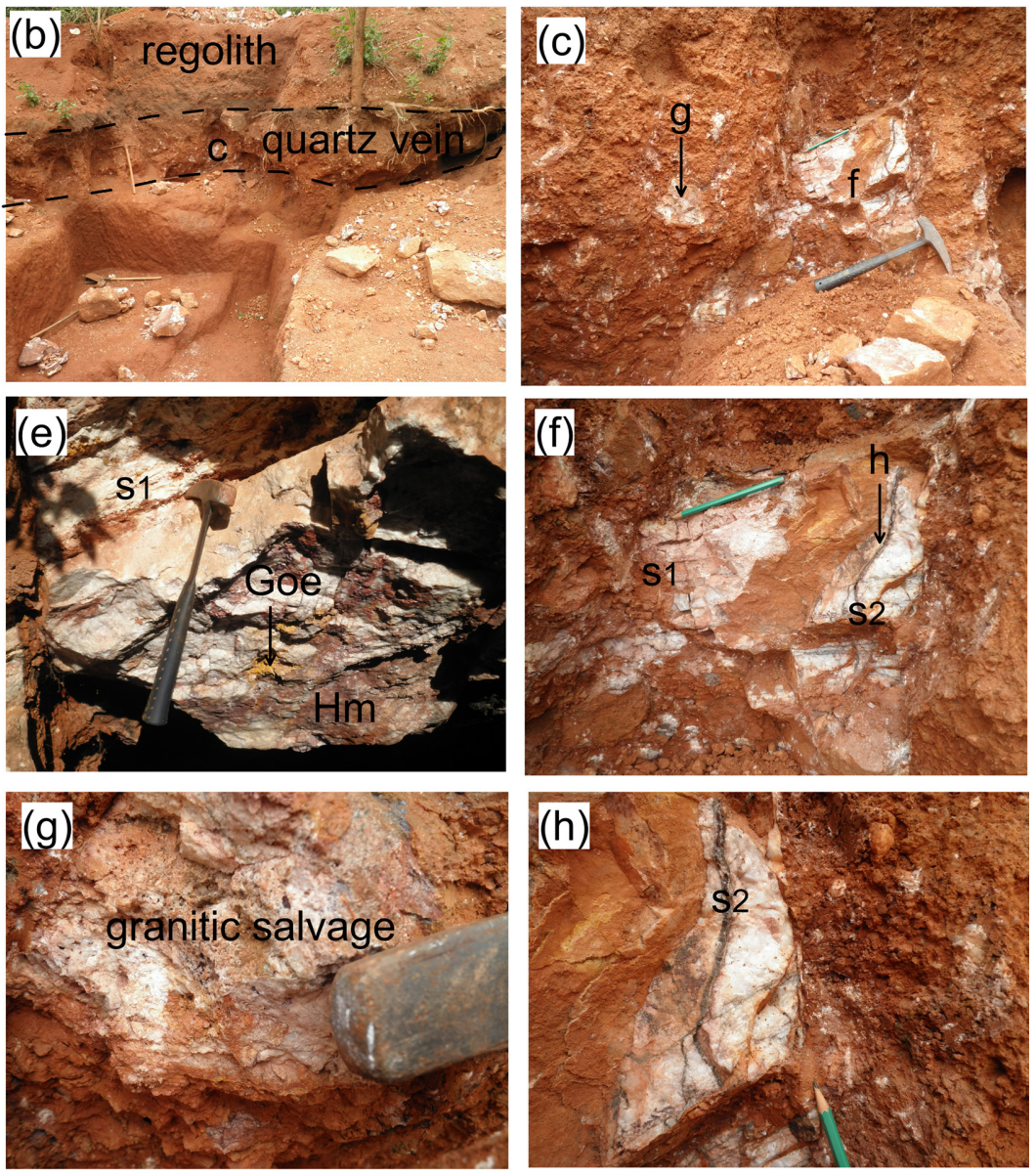

Figure 2. Quartz vein characterization in Mama. a) Section of the Mama vein system. (b) Mama vein system exposed on the western flank of a 33.4 by 11.5 m artisanal mining pit with a regolith thickness of $20 \mathrm{~cm}$. (c) Quartz vein exposed along the vein host rock boundary. Notice the wallrock salvage. (d) Section of the quartz vein revealing $S 1$ foliation. (e) Brecciated quartz vein with fractures defined by hematite. Notice the $S 1$ foliations. (f) Section of the vein system showing $S 1$ and $S 2$ foliations. (g) Close view of the granitic selvage at the contact between the quartz vein and the granitic host rock. (h) Close view of the $S 2$ foliation (i) Contact between the quartz vein and granite characterized by sericite alteration (yellowish). 


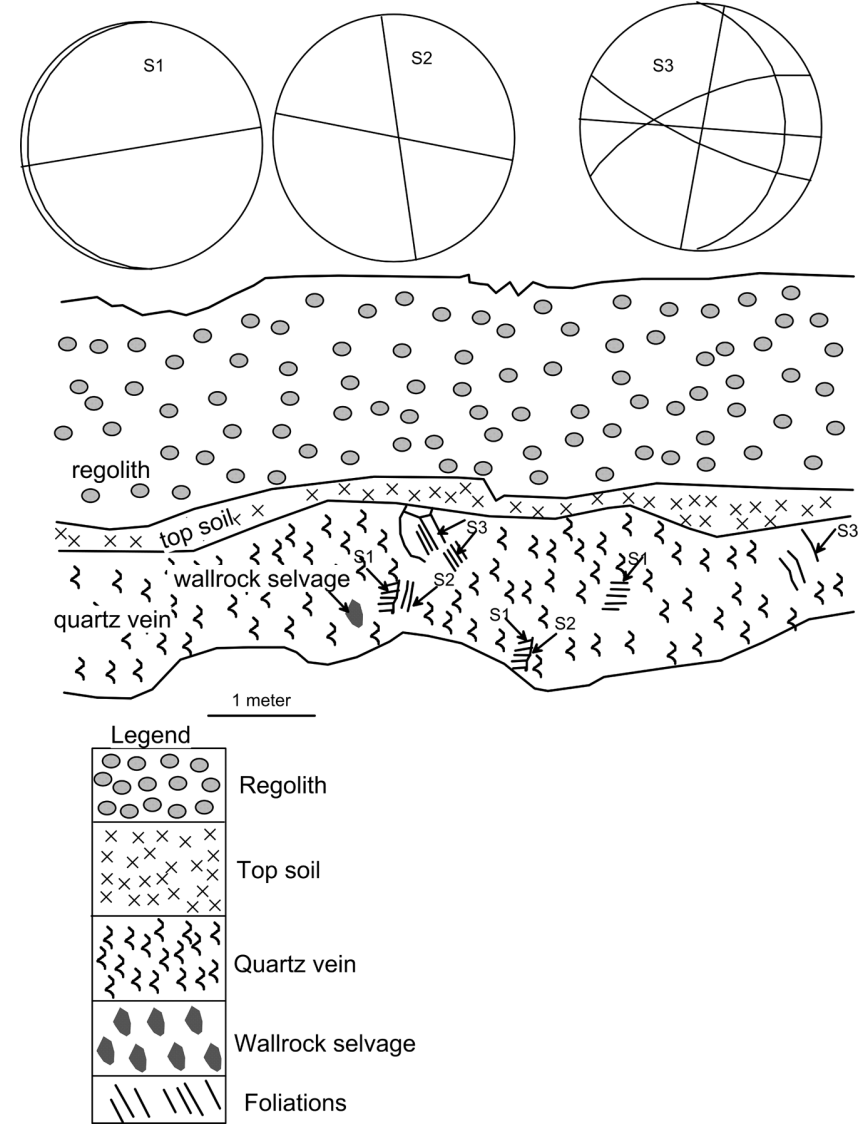

Figure 3. Structural profile of the Mama quartz vein system, Batouri. Notice three foliations $S 1, S 2, S 3$ and a wallrock selvage associated with the quartz vein. The vein is shallow and shows a regolith thickness of $20 \mathrm{~cm}$.
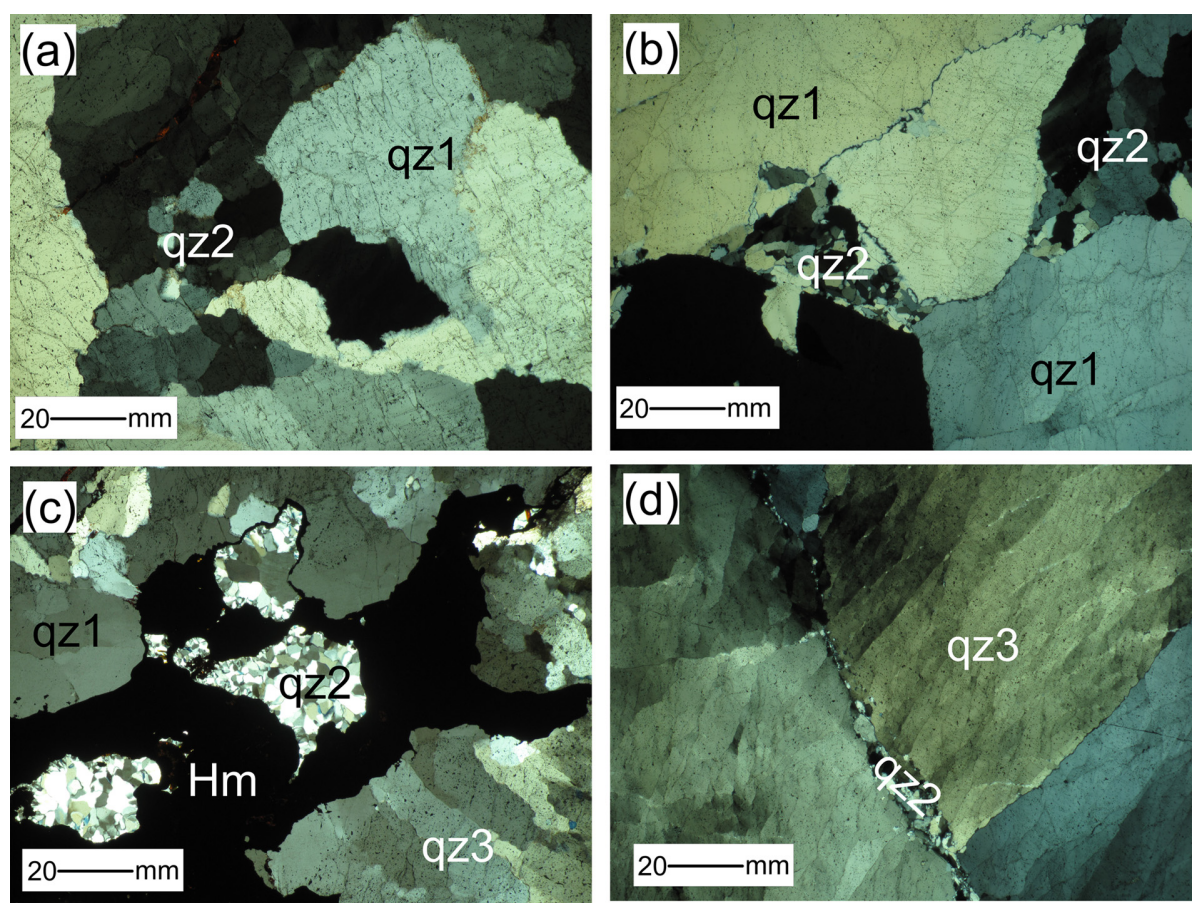

Figure 4. Photomicrograph showing quartz textures in the auriferous Mama vein system Batouri (a,b,c) Characteristic quartz textures in the mineralized and bulk quartz from Mama. (d) Re-crystallized quartz (qz2) defining the grain boundary of coarse-grained quartz in samples. Abbreviations: $q z 1=$ first quartz generation, qz2=second quartz generation, qz3=third quartz generation. mineralized quartz veins exhibit S1 and S2 foliations (Figs. 2 and 3). The $\mathrm{S} 1$ foliation follows a general E-W trend and it is marked by distinct hematite bands truncated by S2 surfaces. The S2 foliation is defined by mm-scale slickenside coating and the surfaces are crosscut by N-S-trending hematite-bearing veinlets (Fig. 2). These veinlet are zoned; hematite in the core and silica along the margins. The barren quartz veins are late and follow S3 surfaces.

\section{Vein Texture and Alteration Mineralogy}

The veins show a wide variation in texture (Figs. 4 and 5). Hematite-rich quartz veins are either banded or brecciated. Some show a characteristic stock work texture comprising a network of narrow discontinuous and closely spaced fractures. Brecciation is enhanced by transgranular fractures thus hematite distribution within the brecciated quartz vein is fracture-controlled. The mineralized quartz veins are defined by rose to milky white vuggy quartz. Although some of these vugs are empty, most are filled with euhedral quartz crystals and sulphides. The barren veins in contrast are composed predominantly of whitish-vuggy quartz. Unlike the barren veins the mineralized veins have carbonate, hematite, goethite, sulphides and gold. Three generations of quartz based on morphology have been identified (Fig. 4). They include coarse-grained quartz with deformed grain boundaries (qz1, Fig. 4), incipient recrystallized quartz (qz2) defined by small polygonal quartz grains and subgrains occupying intergrain planes mainly parallel to the grain boundaries and vein margins (Fig. 4) and deformed-elongated (stretched) quartz ribbons (qz3). The quartz crystals display undulate extinction (Fig. 4).

Pyrite is euhedral, vesicular and in some cases it is fractured (Fig. 5) and/or crosscut by quartz + hematite veins (Fig. 5). Chalcopyrite inclusions are common in pyrite. Carbonate occurs in association with the granitic selvage and sericite is abundant at the contact with the granitic wall rock. Gold occurs as inclusions in hematite (Fig. 5e, g, h, i) and it is intergrown with covellite and sphalerite forming tiny slender crystals (Fig. 5). Goethite occurs around the rims of hematite. Alteration processes thus identified in the Mama quartz vein system include: silicification, carbonatization, sericitization, hematitization, sulphidation and carbonitization.

\section{Sulphide and Gold Microchemistry}

Data from EMP-analyses of sulphides and gold from the quartz vein system are summarized in Table 1. Pyrite has 0.13 to 0.34 wt.\% $\mathrm{Au}$ and minor amounts of As. Analyses on gold grains yielded gold content that varies between 59.74 and 60.33 wt.\% and a Ag content that varies from 36.9 to 37.7 wt.\%. This confirms the EDS patterns of gold grains that indicate that the grains are rich in $\mathrm{Ag}$. $\mathrm{Au}$ shows a fineness that ranges from 609 to 615 (Table 1). 

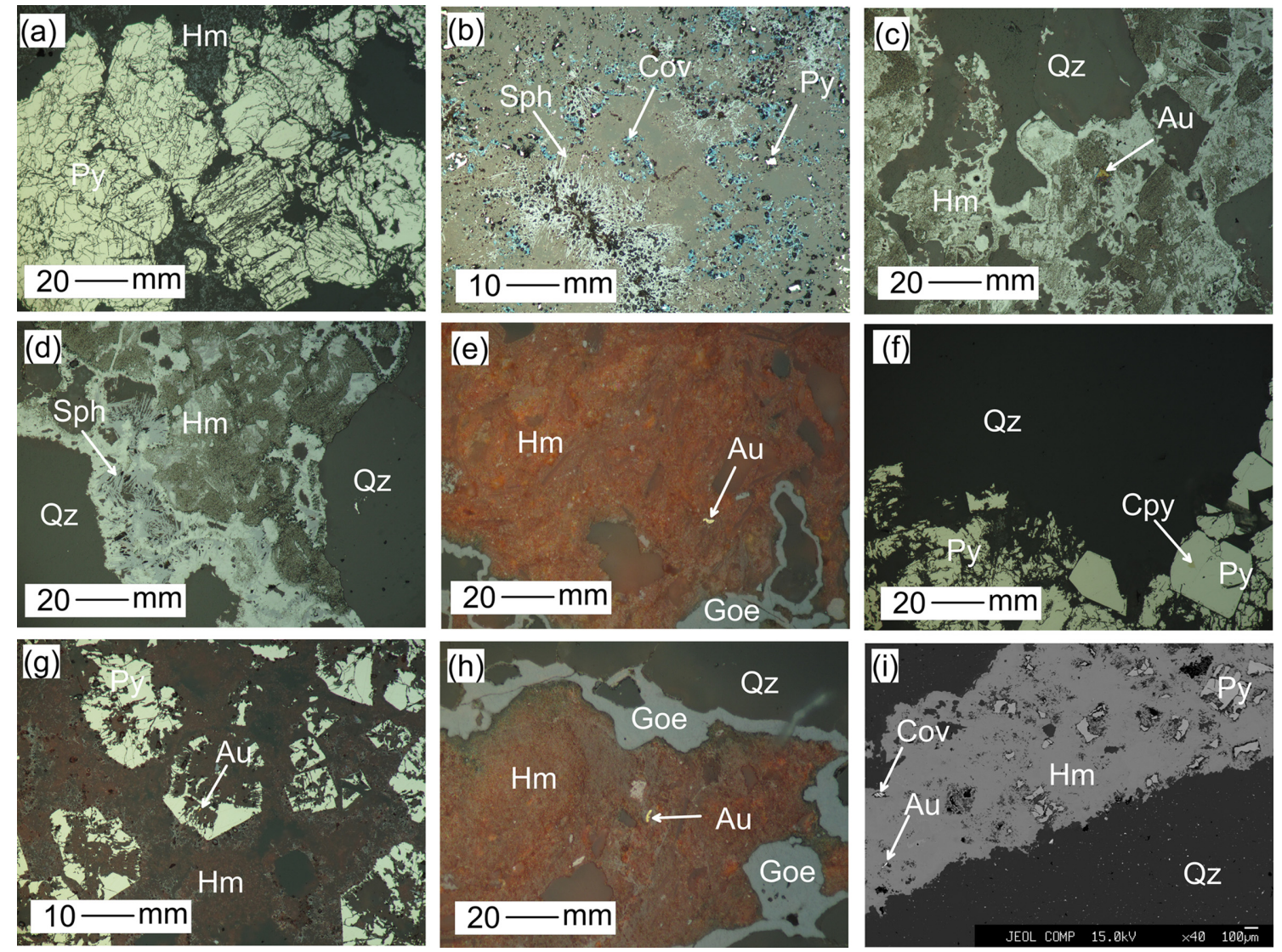

Figure 5. Photomicrographs and COMP image of the Mama vein system samples indicating the various mineral assemblages within the vein system (a) Deformed pyrite and hematite. (b) Covellite, pyrite and sphalerite in association with hematite. (c) Gold inclusion in hematite. (d) Sphalerite and hematite inclusions in quartz. (e) Gold nugget in hematite. (f) Chalcopyrite inclusion in pyrite. (g) Deformed pyrite rimmed by hematite. Notice the gold grain in hematite. (h) Gold inclusion in hematite. The hematite is altered to goethite. (i) Composition image of the vein indicating gold, covellite and pyrite inclusion in hematite. Photomicrographs were taken under reflected light and uncrossed nicols. Abbreviations: $Q z=$ quartz, $P y=$ pyrite, $C p y=$ chalcopyrite, $S p h=$ sphalerite, $\mathrm{Hm}=$ hematite, $C o v=c o v e l l i t e, A u=g o l d$.

\section{Trace Element Geochemistry}

The concentrations of trace elements in bulk quartz vein samples from the Mama vein system are listed in Table 2. The veins are characterized by a $\mathrm{Au}+\mathrm{As}+\mathrm{Hg}+\mathrm{Zn}+\mathrm{Pb}+\mathrm{Sb}+\mathrm{Mo}$ association with 0.04 ppm Au, 44.9 ppm As, 57 ppm Hg, 650 ppm Zn, 489 ppm Pb, 5 ppm $\mathrm{Sb}$ and $25 \mathrm{ppm}$ Mo. It also contains elevated concentrations of Co (155 ppm), Cu (77 ppm), U (3.7 ppm) and Ba (10 ppm, Table 2).

\section{Fluid Inclusion Petrography and Microthermometry}

Typical morphologies of fluid inclusion from quartz vein samples are illustrated in Fig. 6 and their microthemometric measurements are pesented in Table 3 and Fig. 7. The inclusions occur as scattered groups or clusters trapped in coarse-fine-grained and ribbon quartz. Based on the host vein, petrographic chracteristics and relative timing, the fluid inclusions can be divided into: early (intragranular) and late (occurs as trails in healed fractures and define grain boundaries). The monophase inclusions mainly define gain boundaries or healed fractures although a few intragranular inclusions have been identified. The microthermometric data including $\mathrm{Tm}$ and Th for inclusions in all the quartz varieties are given in Fig. 7. Although the inclusions show a wide range of $\mathrm{Tm}$ in all the quartz generations, a distinct Tm ranging from -5.5 to -3 and homogenization temperature varying between 230 and $330^{\circ} \mathrm{C}$ can be identified. Although the calculated salinities for fluid inclusions range from 0.50 to 9.05 wt.\% $\mathrm{NaCl}_{\text {equivalent, }}$, a cluster between 4.23 and 9.05 wt. $\% \mathrm{NaCl}_{\text {equivalent }}$ is also discernible. This is slightly higher than seawater salinity.

\section{Sulfur Isotopes}

The $\delta^{34} \mathrm{~S}$ values vary between 4.8 and $5.3 \%$ o $\delta^{34} \mathrm{~S}$. These values overlap with those of the Bétaré Oya vein system (Vishiti et al., 2017) and are discussed further hereafter.

\section{Interpretation and Discussion}

\section{Structural Configuration of the Mama Vein System}

The Mama vein system is structurally controlled mainly by a NESW-trending shear zone that would have contributed significantly to gold mineralization. Recent studies (e.g. Suh and Lehmann, 2003; Suh et al., 2006; Suh, 2008; Fon et al., 2012; Vishiti et al., 2017; Wambo 
Table 1. Electron microprobe analysis data of pyrite and gold from the Mama vein system in Batouri. All the analyses are reported in wt\%

\begin{tabular}{|c|c|c|c|c|c|c|c|c|c|c|c|c|c|c|c|c|c|c|c|c|c|c|}
\hline \begin{tabular}{|c|} 
Sample \\
No
\end{tabular} & $\begin{array}{c}\text { Analyses } \\
\text { No }\end{array}$ & $\mathrm{Fe}$ & $\mathrm{S}$ & $\mathrm{Ag}$ & As & $\mathrm{Hg}$ & $\mathrm{Cd}$ & $\mathrm{Sn}$ & $\mathrm{Cu}$ & $\mathrm{Au}$ & $\mathrm{Sb}$ & $\mathrm{Zn}$ & Total & & & $\mathrm{Au}$ & $\mathrm{Ag}$ & As & $\mathrm{Hg}$ & Total & $\mathrm{Au} / \mathrm{Ag}$ & $\begin{array}{c}\text { Fine- } \\
\text { ness }\end{array}$ \\
\hline & DL & 0.01 & 0.01 & 0.01 & 0.35 & 0.02 & 0.01 & 0.01 & 0.01 & 0.12 & 0.01 & 0.03 & & & & 0.21 & 0.01 & 0.71 & 0.06 & & & \\
\hline MA- & 26 & 45.03 & 54.83 & 0.01 & bdl & bdl & bdl & bdl & bdl & 0.14 & bdl & bdl & 100.0 & Gold & 20 & 59.74 & 36.92 & 1.46 & 0.10 & 98.2 & 1.6 & 609 \\
\hline \multirow{24}{*}{ BRE4 } & 27 & 44.95 & 54.58 & bdl & bdl & bdl & 0.01 & bdl & bdl & bdl & 0.02 & 0.03 & 99.6 & & 21 & 60.33 & 37.7 & 1.22 & 0.11 & 99.4 & 1.6 & 615 \\
\hline & 28 & 30.89 & 35.22 & bdl & bdl & bdl & 0.01 & 0.01 & 33.8 & bdl & bdl & bdl & 99.9 & & & & & & & & & \\
\hline & 29 & 47.01 & 53.71 & 0.02 & bdl & bdl & bdl & bdl & bdl & bdl & bdl & bdl & 100.6 & & & & & & & & & \\
\hline & 30 & 44.97 & 54.69 & bdl & bdl & 0.02 & 0.01 & bdl & 0.02 & bdl & bdl & bdl & 99.7 & & & & & & & & & \\
\hline & 31 & 47.22 & 53.84 & bdl & bdl & bdl & bdl & bdl & 0.01 & bdl & 0.01 & 0.03 & 101.1 & & & & & & & & & \\
\hline & 32 & 46.88 & 53.41 & 0.01 & bdl & bdl & 0.03 & bdl & bdl & 0.21 & 0.01 & bdl & 100.6 & & & & & & & & & \\
\hline & 33 & 47.02 & 53.78 & bdl & bdl & bdl & bdl & bdl & bdl & bdl & 0.02 & 0.03 & 100.9 & & & & & & & & & \\
\hline & 35 & 47.08 & 53.64 & bdl & bdl & bdl & 0.01 & bdl & bdl & bdl & bdl & bdl & 100.7 & & & & & & & & & \\
\hline & 36 & 45.63 & 54.07 & 0.01 & bdl & bdl & 0.02 & bdl & 0.03 & bdl & bdl & bdl & 99.8 & & & & & & & & & \\
\hline & 37 & 44.96 & 53.96 & bdl & bdl & 0.05 & 0.01 & bdl & 0.02 & bdl & bdl & 0.03 & 99.0 & & & & & & & & & \\
\hline & 38 & 45.87 & 53.98 & 0.01 & bdl & bdl & bdl & bdl & bdl & 0.15 & 0.04 & bdl & 100.5 & & & & & & & & & \\
\hline & 39 & 45.91 & 53.86 & bdl & bdl & bdl & 0.01 & bdl & bdl & bdl & bdl & 0.04 & 99.8 & & & & & & & & & \\
\hline & 40 & 45.35 & 53.78 & bdl & bdl & bdl & 0.02 & bdl & 0.01 & bdl & 0.02 & bdl & 99.2 & & & & & & & & & \\
\hline & 41 & 45.26 & 53.91 & bdl & bdl & 0.02 & 0.02 & bdl & 0.03 & 0.13 & 0.01 & bdl & 99.4 & & & & & & & & & \\
\hline & 42 & 45.72 & 53.82 & 0.01 & bdl & bdl & 0.01 & 0.01 & bdl & 0.34 & bdl & 0.05 & 99.9 & & & & & & & & & \\
\hline & 43 & 44.87 & 53.79 & bdl & bdl & bdl & bdl & bdl & bdl & bdl & bdl & 0.06 & 98.7 & & & & & & & & & \\
\hline & 44 & 45.32 & 53.46 & bdl & bdl & bdl & bdl & bdl & 0.01 & bdl & 0.02 & 0.06 & 98.9 & & & & & & & & & \\
\hline & 98 & 46.75 & 53.18 & 0.01 & bdl & 0.04 & bdl & 0.01 & bdl & bdl & 0.01 & 0.03 & 100.0 & & & & & & & & & \\
\hline & 100 & 46.75 & 53.25 & bdl & bdl & bdl & 0.01 & 0.01 & bdl & bdl & bdl & bdl & 100.0 & & & & & & & & & \\
\hline & 101 & 46.78 & 53.18 & bdl & bdl & 0.02 & bdl & 0.01 & bdl & bdl & 0.01 & bdl & 100.0 & & & & & & & & & \\
\hline & 102 & 46.65 & 52.76 & bdl & bdl & bdl & 0.02 & bdl & bdl & bdl & 0.01 & bdl & 99.4 & & & & & & & & & \\
\hline & 103 & 46.67 & 52.99 & bdl & bdl & bdl & 0.02 & bdl & bdl & bdl & 0.04 & bdl & 99.7 & & & & & & & & & \\
\hline & 104 & 46.80 & 53.12 & bdl & bdl & bdl & 0.01 & bdl & 0.04 & bdl & 0.01 & bdl & 99.9 & & & & & & & & & \\
\hline & 105 & 46.73 & 52.90 & 0.01 & 0.46 & bdl & 0.02 & bdl & bdl & bdl & 0.01 & bdl & 100.1 & & & & & & & & & \\
\hline
\end{tabular}


Table 1. Continued

\begin{tabular}{|c|c|c|c|c|c|c|c|c|c|c|c|c|c|c|c|c|c|c|c|c|}
\hline $\begin{array}{c}\text { Sample } \\
\text { No }\end{array}$ & $\begin{array}{c}\text { Analyses } \\
\text { No }\end{array}$ & $\mathrm{Fe}$ & $\mathrm{S}$ & $\mathrm{Ag}$ & As & $\mathrm{Hg}$ & $\mathrm{Cd}$ & $\mathrm{Sn}$ & $\mathrm{Cu}$ & $\mathrm{Au}$ & $\mathrm{Sb}$ & $\mathrm{Zn}$ & Total & $\mathrm{Au}$ & $\mathrm{Ag}$ & As & $\mathrm{Hg}$ & Total & $\mathrm{Au} / \mathrm{Ag}$ & $\begin{array}{c}\text { Fine- } \\
\text { ness }\end{array}$ \\
\hline MA- & 106 & 46.91 & 53.27 & bdl & bdl & 0.02 & 0.01 & bdl & bdl & bdl & bdl & bdl & 100.2 & & & & & & & \\
\hline \multirow[t]{19}{*}{ BRE3 } & 107 & 46.56 & 53.18 & 0.01 & bdl & bdl & 0.03 & bdl & bdl & bdl & bdl & bdl & 99.8 & & & & & & & \\
\hline & 111 & 46.90 & 53.77 & 0.01 & bdl & bdl & 0.01 & bdl & 0.03 & bdl & 0.01 & bdl & 100.7 & & & & & & & \\
\hline & 112 & 46.89 & 53.90 & bdl & bdl & bdl & 0.01 & bdl & 0.01 & bdl & 0.02 & bdl & 100.8 & & & & & & & \\
\hline & 114 & 46.82 & 53.77 & bdl & bdl & bdl & 0.02 & bdl & bdl & bdl & 0.02 & bdl & 100.6 & & & & & & & \\
\hline & 115 & 47.02 & 54.04 & bdl & bdl & bdl & bdl & bdl & 0.02 & bdl & bdl & bdl & 101.1 & & & & & & & \\
\hline & 116 & 46.95 & 53.85 & bdl & bdl & 0.02 & 0.01 & bdl & 0.03 & bdl & bdl & bdl & 100.9 & & & & & & & \\
\hline & 117 & 47.03 & 53.77 & bdl & bdl & bdl & 0.01 & bdl & bdl & bdl & 0.03 & bdl & 100.8 & & & & & & & \\
\hline & 118 & 47.09 & 53.99 & bdl & bdl & bdl & bdl & bdl & bdl & bdl & bdl & bdl & 101.1 & & & & & & & \\
\hline & 119 & 47.02 & 54.09 & bdl & bdl & 0.02 & 0.02 & bdl & 0.03 & bdl & bdl & bdl & 101.2 & & & & & & & \\
\hline & 120 & 47.00 & 53.94 & bdl & bdl & bdl & bdl & bdl & 0.01 & bdl & 0.03 & bdl & 100.9 & & & & & & & \\
\hline & 121 & 46.92 & 53.84 & bdl & bdl & bdl & bdl & bdl & bdl & bdl & 0.01 & bdl & 100.8 & & & & & & & \\
\hline & 123 & 47.00 & 53.65 & bdl & bdl & bdl & bdl & bdl & 0.01 & bdl & bdl & bdl & 100.7 & & & & & & & \\
\hline & 124 & 47.03 & 54.12 & bdl & bdl & bdl & 0.01 & bdl & bdl & bdl & bdl & bdl & 101.2 & & & & & & & \\
\hline & 125 & 46.99 & 53.94 & bdl & bdl & bdl & 0.01 & bdl & 0.06 & bdl & 0.02 & bdl & 101.0 & & & & & & & \\
\hline & 126 & 47.01 & 53.93 & bdl & bdl & bdl & 0.02 & bdl & bdl & bdl & bdl & bdl & 100.9 & & & & & & & \\
\hline & 127 & 46.90 & 53.69 & bdl & bdl & bdl & bdl & bdl & bdl & 0.20 & 0.03 & bdl & 100.8 & & & & & & & \\
\hline & 128 & 47.16 & 53.36 & bdl & bdl & bdl & 0.01 & bdl & bdl & bdl & 0.02 & 0.03 & 100.6 & & & & & & & \\
\hline & 129 & 47.13 & 54.05 & 0.01 & bdl & bdl & bdl & bdl & bdl & bdl & bdl & bdl & 101.2 & & & & & & & \\
\hline & 130 & 47.25 & 53.85 & bdl & bdl & 0.02 & 0.02 & bdl & bdl & bdl & bdl & bdl & 101.1 & & & & & & & \\
\hline
\end{tabular}


Table 2. Trace element composition of the Mama mineralized vein samples

\begin{tabular}{|c|c|c|c|}
\hline Location & & Batouri & \\
\hline Sample ID & $\overline{\mathrm{DL}}$ & MA-BRE3 & MA-BU \\
\hline $\mathrm{Au}(\mathrm{ppm})$ & 0.002 & 0.04 & 0.024 \\
\hline $\mathrm{Ag}$ & 5 & bdl & bdl \\
\hline As & 0.5 & 44.9 & 1.3 \\
\hline B & 10 & 20 & 10 \\
\hline $\mathrm{Ba}$ & 3 & 10 & 13 \\
\hline $\mathrm{Be}$ & 3 & bdl & bdl \\
\hline $\mathrm{Bi}$ & 2 & bdl & bdl \\
\hline $\mathrm{Br}$ & 0.5 & bdl & 1.1 \\
\hline $\mathrm{Cd}$ & 0.2 & bdl & bdl \\
\hline $\mathrm{Ce}$ & 0.8 & bdl & bdl \\
\hline Co & 1 & 155 & bdl \\
\hline $\mathrm{Cr}$ & 5 & bdl & bdl \\
\hline Cs & 0.1 & bdl & bdl \\
\hline $\mathrm{Cu}$ & 2 & 77 & bdl \\
\hline Dy & 0.3 & bdl & bdl \\
\hline $\mathrm{Er}$ & 0.1 & 0.1 & bdl \\
\hline $\mathrm{Eu}$ & 0.2 & bdl & bdl \\
\hline $\mathrm{Ga}$ & 0.2 & 3.2 & $\overline{b d l}$ \\
\hline$\overline{\mathrm{Gd}}$ & 0.1 & 0.2 & $\overline{b d l}$ \\
\hline $\mathrm{Ge}$ & 0.1 & 4.6 & 1.5 \\
\hline $\mathrm{Hg}$ & 1 & 57 & 6 \\
\hline $\mathrm{Hf}$ & 1 & bdl & bdl \\
\hline Ho & 0.2 & bdl & bdl \\
\hline In & 0.2 & bdl & bdl \\
\hline Ir & 5 & $\mathrm{bdl}$ & $\overline{b d l}$ \\
\hline $\mathrm{La}$ & 0.5 & 0.8 & bdl \\
\hline $\mathrm{Li}$ & 3 & bdl & bdl \\
\hline $\mathrm{Lu}$ & 0.05 & bdl & bdl \\
\hline $\mathrm{Mn}$ & 3 & 59 & bdl \\
\hline Mo & 1 & 25 & bdl \\
\hline $\mathrm{Nb}$ & 2.4 & bdl & bdl \\
\hline $\mathrm{Nd}$ & 0.4 & 0.5 & bdl \\
\hline $\mathrm{Ni}$ & 10 & 10 & bdl \\
\hline $\mathrm{Pb}$ & 0.8 & 489 & 14.4 \\
\hline $\operatorname{Pr}$ & 0.1 & 0.2 & bdl \\
\hline $\mathrm{Rb}$ & 15 & bdl & bdl \\
\hline $\mathrm{Sb}$ & 0.1 & 5 & 0.3 \\
\hline Sc & 0.1 & 0.3 & 0.1 \\
\hline $\mathrm{Se}$ & 3 & bdl & bdl \\
\hline $\mathrm{Sm}$ & 0.1 & 0.1 & bdl \\
\hline Sn & 0.5 & bdl & bdl \\
\hline $\mathrm{Sr}$ & 3 & 10 & 7 \\
\hline $\mathrm{Ta}$ & 0.5 & bdl & bdl \\
\hline $\mathrm{Tb}$ & 0.2 & bdl & bdl \\
\hline $\mathrm{Te}$ & 6 & bdl & bdl \\
\hline Th & 0.1 & bdl & bdl \\
\hline $\mathrm{Tl}$ & 0.1 & bdl & bdl \\
\hline $\mathrm{Tm}$ & 0.1 & bdl & bdl \\
\hline $\mathrm{U}$ & 0.2 & 3.7 & 0.1 \\
\hline $\mathrm{V}$ & 2 & 47 & 10 \\
\hline $\mathrm{W}$ & 1 & 5 & bdl \\
\hline $\mathrm{Y}$ & 0.1 & 1 & bdl \\
\hline $\mathrm{Yb}$ & 0.1 & 0.1 & bdl \\
\hline $\mathrm{Zn}$ & 50 & 650 & bdl \\
\hline Fe wt $\%$ & & 12.5 & 0.14 \\
\hline S (T) & & 0.5 & 0.03 \\
\hline
\end{tabular}
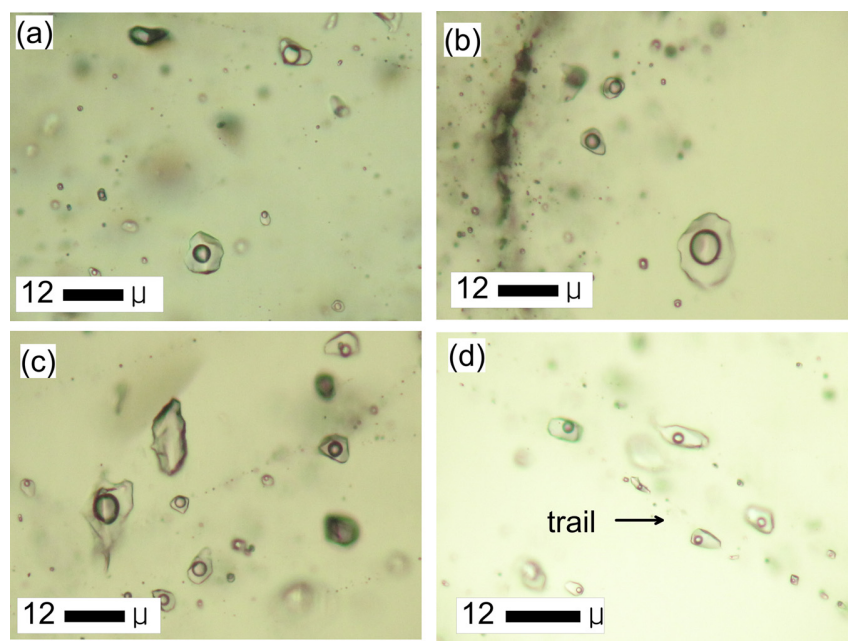

(d)

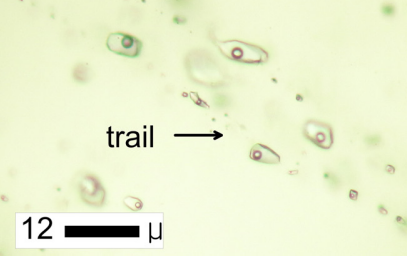

Figure 6. Photomicrographs of typical liquid rich fluid inclusions in quartz vein from the Mama vein system Batouri. Monophase liquid and vapour inclusions are also widespread. Note the vapor bubble in most of the inclusions.

et al., 2018) have highlighted the importance of this shear zone to gold mineralization in the eastern region of Cameroon. Field evidence shows that shearing in this zone is ductile and was followed by brittle deformation that post-dates the emplacement of the Au quartz veins. Samples from the Mama vein system bear evidence of protracted progressive deformation at macroscopic and microscopic scales. Ribbon quartz attests to ductile deformation along the shear zone superimposed on various precursor stages of brittle failure documented by the abundance of breccias. These deformation structures focused and enhanced crustal fluid circulation and mineralization. Whether the shearing was contemporaneous with distal granite plutons observed is unclear, however the felsic magmatism is implicated in the hydrothermal fluid related to the gold mineralization along these structures. The veins show incorporated wall-rock selvages diagnostic of a shear zone system (Vishiti et al., 2017) but lacks sigmoidal features. The absence of such features renders it difficult to identify the direction of shear which can be used to establish its kinematics. A number of gold mineralization associated with shear zones have been reported worldwide (Harraz, 1999; Khalil et al., 2003; Chiaradia et al., 2008; Zoheir, 2008; Zoheir et al., 2017). The most suitable veins for artisanal mining in this area should have the ductile features itemized above.

\section{Brecciation as a Ground Preparation Event for Mineral- ization}

Faults and shear zones are major fluid conduits in crustal basement (Kerrich, 1986; Knipe, 1993). Breccias are a common product in the highest, most fluid-saturated part of crustal fault zones where the potential for dilation strain increases the range of breccias formation processes (Woodcock and Mort, 2008). Brecciation is an excellent precursor to mineralization, as circulating hydrothermal fluids will readily interact with the fractured rocks. Enhanced permeability created in breccia zones provides pathways for crustal fluids that are sometimes metal- or hydrocarbon-rich (Woodcook and Mort, 2008). Thus breccias are associated with numerous types of ore deposits both 
Table 3. Fluid inclusion petrography and microthermometry for Mama mineralized and barren vein samples

\begin{tabular}{|c|c|c|c|c|c|c|c|c|c|c|c|c|c|c|c|c|c|c|c|c|c|}
\hline Vein type & Quartz texture & $\begin{array}{c}\text { Relative } \\
\text { timing }\end{array}$ & Occurrence & $\begin{array}{c}\text { Fluid inclusion } \\
\text { assemblage }\end{array}$ & \begin{tabular}{|c|}
$\begin{array}{c}\text { Filling grade } \\
\text { vol } \%\end{array}$ \\
\end{tabular} & \begin{tabular}{|c|}
$\begin{array}{c}\text { Size range } \\
(\mu)\end{array}$ \\
\end{tabular} & \multicolumn{5}{|c|}{$\operatorname{Th}\left({ }^{\circ} \mathrm{C}\right)$} & \multicolumn{5}{|c|}{$\operatorname{Tm}\left({ }^{\circ} \mathrm{C}\right)$} & \multicolumn{5}{|c|}{ Salinity $\mathrm{wt} \% \mathrm{NaCl}_{\text {equivalent }}$} \\
\hline & & & & & & & $\mathrm{n}$ & $\min$ & $\max$ & ave & std & $\mathrm{n}$ & $\min$ & $\max$ & ave & std & $\mathrm{n}$ & $\min$ & $\max$ & ave & std \\
\hline Mineralized & Coarse quartz & Early & Intragranular & $\begin{array}{c}\text { Two phase } \\
(\mathrm{L}+\mathrm{V})\end{array}$ & $<10-30$ & $<2-25$ & 63 & 166 & 364 & 275.3 & 40.3 & 66 & -6.9 & -2.8 & -4.3 & 0.8 & 37 & 5.32 & 8.79 & 6.70 & 0.97 \\
\hline \multicolumn{22}{|l|}{ MA-BRE3 } \\
\hline & & Late & $\begin{array}{c}\text { Trails, } \\
\text { grain boundary, } \\
\text { healed fractures }\end{array}$ & $\begin{array}{l}\text { Two phase } \\
(\mathrm{L}+\mathrm{V})\end{array}$ & $11-20$ & 2 & 2 & 251 & 268.9 & 259.9 & 12.6 & 2 & -4.7 & -3.5 & -4.1 & 0.84 & 2 & 5.62 & 7.39 & 6.51 & 1.25 \\
\hline & Fine quartz & Early & Intragranular & $\begin{array}{l}\text { Two phase } \\
(\mathrm{L}+\mathrm{V})\end{array}$ & $\leq 10-30$ & $1-14$ & 19 & 178.9 & 329 & 260.4 & 52.8 & 12 & -5 & -1.1 & -3.6 & 1.3 & 12 & 1.82 & 7.82 & 5.77 & 2.07 \\
\hline & Ribbon quartz & Early & Intragranular & $\begin{array}{c}\text { Two phase } \\
(\mathrm{L}+\mathrm{V})\end{array}$ & $\leq 10-30$ & $<4-16$ & 26 & 200.2 & 309 & 256.5 & 28.7 & 20 & -5.9 & -3.5 & -4.2 & 0.6 & 18 & 5.62 & 9.05 & 6.77 & 0.92 \\
\hline Barren & Coarse quartz & Early & Intragranular & $\begin{array}{c}\text { Two phase } \\
(\mathrm{L}+\mathrm{V})\end{array}$ & $\leq 10-30$ & 4 & 40 & 161.9 & 299.0 & 234.3 & 41.18 & 43 & -5.7 & -0.3 & -3.3 & 1.3 & 39 & 0.50 & 8.79 & 5.2 & 1.9 \\
\hline \multicolumn{22}{|l|}{ MA-BU } \\
\hline & & Late & $\begin{array}{c}\text { Trails, } \\
\text { grain boundary, } \\
\text { healed fractures }\end{array}$ & $\begin{array}{c}\text { Two phase } \\
(\mathrm{L}+\mathrm{V})\end{array}$ & $\leq 10$ & 4 & 6 & 196.1 & 287.2 & 251.7 & 30.7 & 6 & -4.2 & -2.4 & -3.22 & 0.5 & 7 & 3.92 & 6.67 & 5.26 & 0.9 \\
\hline & Fine quartz & Early & Intragranular & $\begin{array}{l}\text { Two phase } \\
(\mathrm{L}+\mathrm{V})\end{array}$ & $\leq 10-30$ & $2-12$ & 19 & 235.6 & 346.6 & 282.9 & 30.2 .2 & 15 & -5.6 & -2.1 & -3.8 & 1.01 & 14 & 1.17 & 8.65 & 5.60 & 2.09 \\
\hline & Ribbon quartz & Early & Intragranular & $\begin{array}{l}\text { Two phase } \\
(\mathrm{L}+\mathrm{V})\end{array}$ & $\leq 10-30$ & $2-14$ & 14 & 245.9 & 330.4 & 283.9. & 22.18 & 26 & -4.9 & -3.1 & -3.86 & 0.55 & 14 & 5.01 & 7.68 & 6.25 & 0.89 \\
\hline
\end{tabular}

$\mathrm{Th}=$ Total homogenization temperature, $\mathrm{Tm}=$ Total ice melting temperature, $\mathrm{n}=$ number of fluid inclusions analyzed, $\min =\operatorname{minimum}, \max =\operatorname{maximum}$, ave $=$ average, std $=$ standard deviation. 

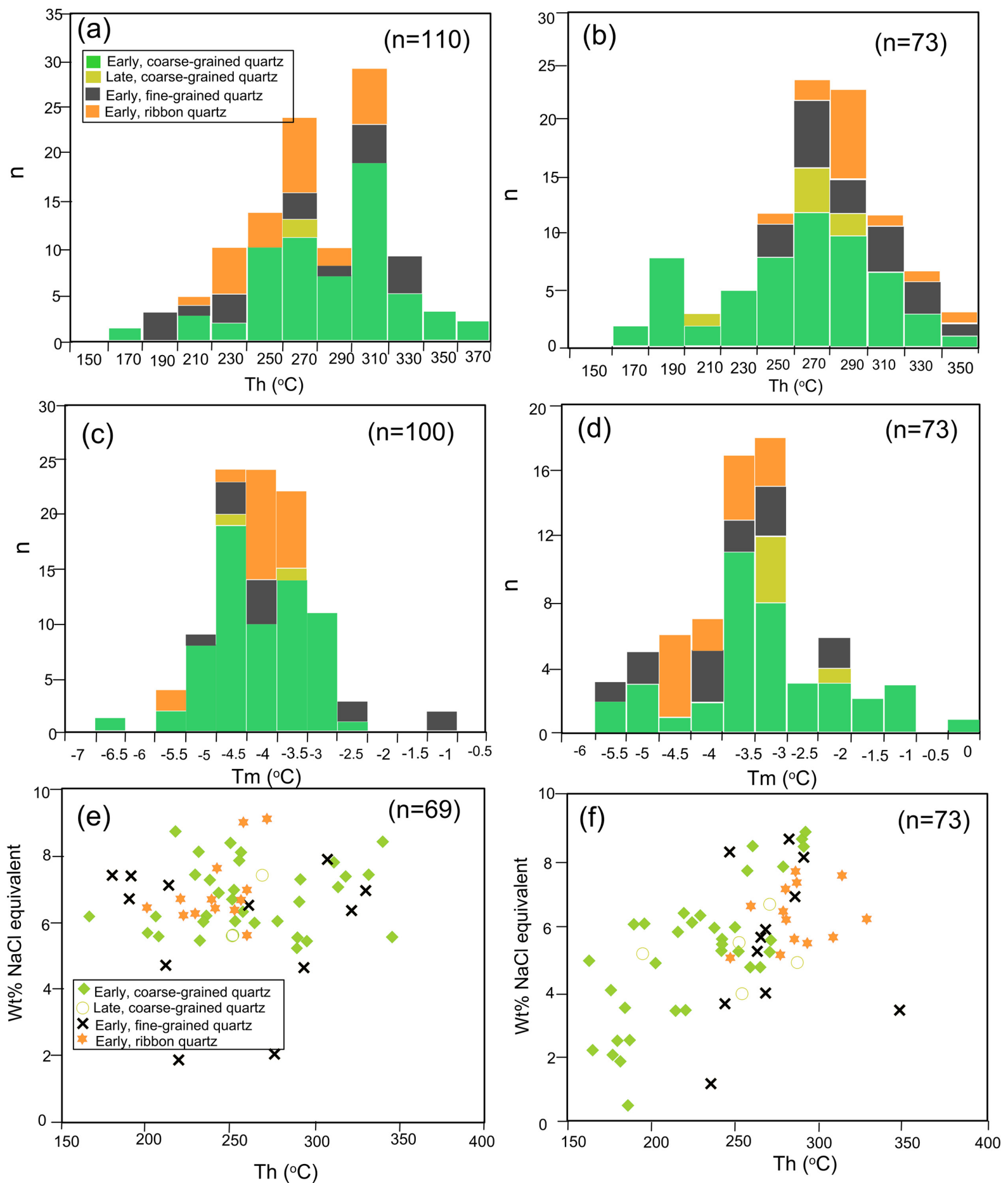

Figure 7. Histograms and XY-scattered plots indicating microthermometric measurements of fluid inclusions in quartz from the Mama vein system eastern Cameroon. The fluid inclusions homogenize into the liquid phase. (a) Frequency histogram for homogenization temperatures (Th) from the Mama mineralized vein system. (b) Frequency histogram for homogenization temperatures (Th) from the Mama barren vein system. (c) Frequency histogram for ice melting (Tm) from the Mama mineralized vein system. (d) Frequency histogram for ice melting (Tm) from the Mama barren vein system. (e, f) Homogenization temperatures and corresponding salinities, from both mineralized and barren vein system.

in surface and subsurface environments (Jebrak, 1997).

Gold mineralization in the Mama Shear zone system is associated with brecciated quartz veins (Fig. 2d, e) in steeply dipping brittle-ductile shear zones. Here brecciation is enhanced by transgranular fracturing. The quartz veins breccias show a characteristic stock work texture with a network of discontinuous and closely spaced fractures that host mineralization. Thus brecciation is a precursor to mineralization as enhanced permeability created during the process of brecciation aid both hydrothermal fluid flow and fluid-rock interaction. As such the breccias act as a matrix for hydrothermal deposits. These 
mineralized breccias are readily amendable to small scale gold mining considering that they are easy to crush.

\section{Alteration Mineralogy and Gold Precipitation}

The Mama quartz veins contain pyrite, chalcopyrite, covellite and sphalerite as the main sulphide minerals together with abundant hematite, goethite, sericite, carbonate and quartz dominated gangue minerals. The main alteration processes indentified within the Mama quartz vein system include: silicification, hematitization, sericitization, carbonitization and sulphidation. It can therefore be classified as a low sulphidation hydrothermal deposit and their formation process is expected to involve a significant proportion of magmatic hydrothermal fluids (Hedenquist and Lowenstern, 1994). Quartz can be divided into three generations, coarse-grained quartz regarded as the first quartz generation and fine-grained to ribbon quartz due to re-crystallization resulting from multiple episodes of deformation and fluid circulation. Sericite occurs at the boundary between the vein and the host rock, carbonate as well as sulphides fills vesicles while hematite defines fractures and is altered around the rims to goethite. The formation of sericite in the altered wallrock increases the permeability along the shear zone since sericite enhances permeability and facilitates ductile deformation (Kurz et al., 2000; Oliver, 2001; White, 2001). Quartz from the Mama Shear zone show a stock work texture with hematite filling fractures. This is similar to mineralization reported by Kreuzer (2006) and Chiaradia et al. (2008). Gold occurs as inclusions in hematite. According to Suh et al. (2006) hydrothermal hematite quartz bands offer the best potential for significant gold concentration. Thus brecciated to stock work hematite-bearing veins in prospective mining sites should be the main target for the local miners since they are the main host of primary mineralization in the eastern region of Cameroon. Quartz from the barren veins is sugary, massive and has a comb texture. According to Kreuzer (2006), massive quartz is deposited during multiple episodes of fracturing and sealing.

EMP-analysis on sulphide reveal gold concentrations that vary from 0.13 to 0.34 wt.\% and very low As contents when compared to As of 4.39 wt.\% in Carlin type gold deposits (Simon et al., 1999(b)). Gold was precipitated from a sulphide-bearing hydrothermal system with a limited substitution of As for Fe or S in pyrite. This may account for the paucity of arsenopyrite in this gold district when compared to similar mesothermal gold deposits (Genkin et al., 1998). Analyses of gold grains show a $\mathrm{Au} / \mathrm{Ag}$ ratio of 1.6 with $\mathrm{Au}$ contents as high as 60.3 wt. $\%$ and a gold fineness of 615 . Visible nuggets exist in the Mama regions as inclusions in hematite. The gold fineness data displayed as maps and charts should therefore enhance the localization of suitable sites for artisanal mining.

\section{Geochemical Characterization of the Quartz Veins}

Bulk geochemical analyses on the gold-quartz veins have identified an $\mathrm{Au}+\mathrm{As}+\mathrm{Hg}+\mathrm{Zn}+\mathrm{Pb}+\mathrm{Sb}+\mathrm{Mo}$ element association characteristic of low sulphidation gold mineralization. The gold quartz vein system is enriched in base metals such as $\mathrm{Cu}, \mathrm{Pb}$ and $\mathrm{Zn}$. Similar quartz veinrelated deposits have been reported by Zhai et al. (2009) in China although the veins are depleted in base metals. Low sulfidation gold deposits associated with alkalic magmatic rocks, demonstrate a clear involvement of magmatic fluid (Sillitoe, 2002; Sillitoe and Hedenquist, 2003). Magmatic fluids are essential to scavenge $\mathrm{Au}$ and $\mathrm{Cu}$ from host magmas, promoted by changing oxygen fugacity during magma evolution, as a result of magnetite crystallization (Sun et al., 2004a) or magma degassing (Burgisser and Scaillet, 2007). At upper crustal levels, the ascending magmatic fluids may mix with seawater (Sun et al., 2004a) depending on the tectonic settings. The presence of $\mathrm{Hg}$ in association with Au suggests that sulphidation led to the precipitation of gold from a Hg-bearing-fluid. Although gold particles can be recovered from weathered vein systems by chemically reacting with liquid $\mathrm{Hg}$ to form gold-mercury amalgam, the presence of $\mathrm{Hg}$ within the quartz vein system can result to contamination and this presents a potential risk to human health and the environment. There is need for constant monitoring of these artisanal mining sites for potential natural $\mathrm{Hg}$ contamination.

\section{Temperature Brackets and Fluid Sources for Gold-Related Alterations}

Fluid inclusions characterized in this study are mainly two phase liquid rich inclusions (Roedder, 1984; Van den Kerkhof and Hein, 2001). Fluid inclusion studies have been used widely to constrain the temperature of hydrothermal activity in numerous gold deposits. Microthermometric data of fluid inclusion form the Mama quartz vein system reflect mesothermal temperatures $\left(230\right.$ to $\left.330^{\circ} \mathrm{C}\right)$ and moderate brine related salinities (4.23 and 9.05 wt.\% $\mathrm{NaCl}_{\text {equivalent }}$ cluster). The distribution of mineralization in quartz veins that crosscut granitic intrusions may suggest that magmatism played an important role in the dynamics of the mineralizing fluids (Soloviev et al., 2013; Tchameni et al., 2013). The variation in vapour/liquid ratio for all the samples studied from Batouri is suggestive of large fluid pressure fluctuation that often reflects multiple episodes of deformation in quartz veins (e.g. Chi and Xue, 2011). During periods of high fluid pressure, the systems were dominated by a deeply sourced fluid related to magmatic activity.

\section{Source of Sulfur}

The Mama quartz vein system is hosted by granitic rocks. The $\delta^{34} \mathrm{~S}$ values for this system reflect a single homogenous source. This directly ties with the fluid inclusion data and demonstrates that the granitic plutons played an important role to Au deposition in this area. Rather than focus only on the quartz vein system, the aureoles of these plutons can also act as a significant target for the artisanal miners in the Batouri gold mining area.

\section{Conclusions}

The following conclusions can be drawn from this study:

1. Gold mineralization in the Mama area is constituted by quartz veins cross-cutting granitoids. Three quartz generations have been identified within the vein system. They include coarse-grained quartz (qtz 1), fined-grained quartz (qtz 2) and ribbon quartz (qtz 3). This indicates multiple episodes of brittle and ductile deformation and fluid flow. Sub-micrometer gold particles occur as inclusions in hematite. 
Associated ore minerals include covellite, carbonate, sphalerite. Thus the following alteration types are recorded in the mama vein system silicification, sulphidation, sericitization, carbonatization and hematitization.

2. Trace element analysis on the veins reveals the $\mathrm{Au}+\mathrm{As}+\mathrm{Hg}+$ $\mathrm{Zn}+\mathrm{Pb}+\mathrm{Sb}+\mathrm{Mo}$ mineral assemblage. This indicates the possibility of low sulphidation Au mineralization in the Batouri gold mining area.

3. Fluid inclusions are generally two phase liquid- rich inclusions. Their analyses indicate a mesothermal temperature bracket for hydrothermal activity in Batouri. Calculated salinities of the fluid inclusions indicate their origin from brines and magmatic sources and this is confirmed by $\delta^{34} \mathrm{~S}$ values.

4. The features listed above are essential in identifying suitable sites for small scale gold miners in the region. They also form the basis for continued field training in cooperation with governmental agencies involved in raising environmental awareness in these communities.

\section{Acknowledgements}

C.E.S. is grateful for the funding from IUGS. Support from the Deutscher Akademischer Austausch Dienst (DAAD) scholarship scheme that allowed for a research stay of Dr. Vishiti A. in GEOMAR Kiel is also acknowledged. The collaborative framework with GEOMAR under the leadership of Prof. Colin Devey and support from Drs. Sven Petersen and Thor Hansteen is greatly acknowledged. This manuscript benefited significantly from comprehensive comments by an anonymous reviewer.

\section{References}

Asaah, A.V., Zoheir, B., Lehmann, B., Frei, D., Burgess, R., and Suh, C.E., 2014 , Geochemistry and geochronology of the $\sim 620$ Ma gold?associated Batouri granitoids, Cameroon. International Geology Review, v. 57, pp. 1485-1509.

Burgisser, A., and Scaillet, B., 2007, Redox evolution of a degassing magma rising to the surface. Nature, v. 445, pp. 94-197.

Castaing, C., Feybesse, J.L., Thieblemont, D., Triboulet, C., and Chevremont, P., 1994, Palaeogeographical reconstructions of the Pan-African/ Braziliano orogen: closure of an oceanic domain or intracontinental convergence between major blocks? Precambrian Research, v. 69, pp. $327-344$.

Chi, G., and Xue, C., 2011, Abundance of $\mathrm{CO}_{2}$-rich fluid inclusions in a sedimentary basin hosted $\mathrm{Cu}$ deposit at Jinman, Yunnan, China: implication for mineralization environment and classification of the deposit. Mineralium Deposita, v. 46, pp. 365-380.

Chiaradia, M., Tripodi, D., and Fontboté, L., 2008, Geological setting, mineralogy and geochemistry of the early Tertiary Au-rich Volcanic Hosted Sulphide deposit of La Plata, Western Cordillera, Ecuador. Economic Geology, v. 103, pp. 161-183.

Fon, A. N., Che, V.B., and Suh, C.E., 2012, Application of electrical resistivity and chargeability data on a GIS platform in delineating auriferous structures in a deeply weathered lateritic terrain, Eastern Cameroon. International Journal of Geosciences, v. 3, pp. 960-971.

Genkin, A.D., Bortnikov, N.S., Cabri, L.J., Wagner, F.E., Stanly, C.J., Safonov, Y.G., Mcnahon, G., Friedl, J., Kerzin, A.L., and Gamyanin, G.N., 1998, A multidisciplinary study of invisible gold in arsenopyrite from four mesothermal gold deposits in Siberia, Russian federation. Economic Geology. v. 93, pp. 463-487.
Hallbauer, D.K., and Utter, T., 1977, Geochemical and morphological characteristics of gold particles from recent river deposits and the fossil placer of the Witwatersrand. Mineralium Deposita, v. 12, pp 293306.

Harraz, H.Z., 1999, Wall rock alteration, Atud gold mine, Eastern Desert Egypt: processes and PTX $\mathrm{CO}_{2}$ conditions of metasomatism. Journal of African Earth Sciences, v. 28, pp. 527-551.

Hedenquist, J.W., and Lowenstern, J.B., 1994, The role of magmas in the formation of hydrothermal ore deposits. Nature, v. 370, pp. 519-527.

Jebrak, M., 1997, Hydrothermal breccias in vein-type deposits; a review of mechanisms, morphology and size distribution. Ore Geology Reviews, v.12, pp. 111-134.

Kerrich, R., 1986, Fluid infiltration into fault zones: chemical isotopic, and mechanical effects. Pure Applied Geophysics, v. 124, pp. 225-268.

Khalil, K.I., Helba, H.A., and Mücke, A., 2003, Genesis of the gold mineralization at the Dungash gold mine area, Eastern Desert, Egypt: a mineralogical-micro chemical study. Journal of African Earth Sciences, v. 37, pp. 111-122.

Knipe, R.J., 1993, The influence of fault zone processes and diagenesis on fluid flow. In: Horbury, A.D., Robinson, A.G. (Eds.), Diagenesis and Basin Development. American Association of Petroleum Geologists studies in Geology, v. 36, pp. 112-126.

Kouske, A.P., Suh, C.E., Ghogomu, R.T., and Ngako, V., 2012, Nametasomatism and uranium mineralization during a two-stage albitization at Kitongo, northern Cameroon: structural and geochemical evidence. International Journal of Geosciences, v. 3, pp. 258-279.

Kreuzer, O.P., 2006, Texture, paragenesis and wall rock alteration of lodegold deposit in the Charter Towers district, North Queensland: implications for the conditions of ore formation. Mineralium Deposita, v. 40, pp. 639-663.

Kurz, W., Unzog, W., Neubauer, F., and Genser, J., 2000, Evolution of quartz microstructures and textures during polyphase deformation within the Tauren window (Eastern Alps). International Journal of Earth Science, v. 90, pp. 361-378.

Li, X-H., Chen, Y., Tchouankoue, J.P., Liu, C.Z., Li, J., Ling, X.X., Tang, G.Q., Liu, Y., 2017, Improving geochronological framework of the Pan-African orogeny in Cameroon: New SIMS zircon and monazite U$\mathrm{Pb}$ age constraints. Precambrian Research, v. 294, pp. 307-321.

Neto, J.A.S., Legrand, J.M., Volfinger, M., Pascal, M.L., and Sonnet, P., 2008, W-Au skarns in the Neo?Proterozoic Seridó Mobile Belt, Borborema Province in northeastern Brazil: An overview with emphasis on the Bonfim deposit. Mineralium Deposita, v. 43, pp. 185-205.

Ngako, V., Affaton, P., Nnange, J.M., and Njanko, Th., 2003, Pan-African tectonics evolution in the central and southern Cameroon: transpression and transtension during sinistral shear movement. Journal of African Earth Sciences, v. 36, pp. 207-214.

Oliver, N.H.S., 2001, Linking of regional and local hydrothermal systems in mid-crust by shearing and faulting. Tectonophysics, v. 335, pp. 147161.

Roedder, E., 1984, Fluid inclusions. Reviews in Mineralogy, v.12, 644 p.

Sillitoe, R.H., 2002, Some metallogenic features of gold and copper deposits related to alkaline rocks and consequences for exploration. Mineralium Deposita, v. 37, pp. 4-13.

Sillitoe, R.H., and Hedenquist, J.W., 2003, Linkage between volcanotectonic settings, ore fluid composition, and epithermal precious metal deposits. In: Simmons, S.F., Graham, I. (Eds.), Volcanic, Geothermal, and Ore-forming Fluids: Rulers and Witnesses of Processes within the Earth: Society of Economic Geologists Special Publication, v. 10, pp. 315-343.

Simon, G., Huang, H., Penner-Hahn, J.E., Kesler, S.E., and Kao, L., 1999b, Oxidation state of gold and arsenic in gold-bearing arsenian pyrite. Amererican Mineralogist, v. 84, pp. 1071-1688.

Soloviev, S.G., Kryazhev, S.G., and Dvurechenskaya, S.S., 2013, Geology, mineralization, stable isotope geochemistry, and fluid inclusion characteristics of the Novogodnee-Monto oxidized $\mathrm{Au}-(\mathrm{Cu})$ skarn and 
porphyry deposit, Polar Ural, Russia. Mineralium Deposita, v. 48, pp. 603-627.

Suh, C.E., 2008, Sulphide microchemistry and hydrothermal fluid evolution in quartz veins, Batouri gold district (southeast Cameroon). Journal of the Cameroon Academy of Sciences, v. 8, pp. 19-30.

Suh, C.E., and Lehmann, B., 2003, Morphology and Electron-probe Microanalysis of Residual gold-grain at Dimako, south east Cameroon. Neues Jabrbuch für Mineralogie Monatshefte, v. 6, pp. 225-275.

Suh, C.E., Lehmann, B., and Mafany, G.T., 2006, Geology and geochemical aspects of lode gold mineralization at Dimako-Mboscorro SE Cameroon. Geochemistry: Exploration, Environment, Analysis, v. 6, pp. 295-309.

Sun, W.D., Arculus, R.J., Kamenetsky, V.S., and Binns, R.A., 2004a, Release of gold-bearing fluids in convergent margin magmas prompted by magnetite crystallization. Nature, v. 431, pp. 975-978.

Tata, E., Suh, C.E., Vishiti, A., Shemang, E.M., Fon, A.N., Ateh, K.I., Chombong, N.N., 2018, Wallrock alteration categories and their geochemical signatures in gold-bearing Neoproterozoic granitoids, Batouri gold district, southeastern Cameroon. Geochemistry: Exploration, Environment, Analysis. https://doi.org/10.1144/geea2016-017

Tchameni, R., Doumnang, J.C., Deudibaye, M. and Branquet, Y., 2013, On the occurrence of gold mineralization in the Pala Neoproterozoic formations, South-Western Chad. Journal of African Earth Sciences, v. 84, pp. 36-46.

Toteu, S.F., Penaye, J., and Poudjom, D.Y., 2004, Geodynamic evolution of the Pan-African belt in Central Africa with special reference to Cameroon. Canadian Journal of Earth Science, v. 41, pp. 73-85.

Toteu, S.F., Penaye, J., Deloule, E., Van Schmus, W.R., and Tchameni, R., 2006, Diachronous evolution of volcano-sedimentary basins North of the Congo craton: Insights from U-Pb ion microprobe dating of zircons from the Poli, Lom and Yaounde' Groups (Cameroon). Journal of African Earth Sciences, v, 44, pp. 428-442.

Toteu, S.F., Van Schmus, R.W., Penaye, J., and Nyobe, J.B., 1994, U-Pb and Sm-Nd evidence for Eburnean and Pan-African high grade metamorphism in cratonic rocks of southern Cameroon. Precambrian Research, v. 67, pp. 321-347.

Ulrich, T., Günther, D., and Heinrich, C.A., 1999, Gold concentration of magmatic brines and the metal budget of porphyry copper deposits. Nature, v. 399, pp. 676-679.

Van den Kerkhof, A.M. and Hein U. F., 2001, Fluid inclusion petrography. Lithos, v. 55, pp. 27-47.

Van Schmus, W.R., Oliveira, E.P., Da Silva Filho, A.F., Toteu, S.F., Penaye, J., and Guimarães, I.P., 2008, The Central African Fold Belt Proterozoic links between the Borborema Province, NE Brazil, and the Central African Fold Belt. Geological Society, London, Special Publications, v. 294, pp. 69-99.

Vishiti, A., Suh, C.E., Lehmann, B., Egbe, J.A., and Shemang, E.M., 2015, Gold grade variation and particle microchemistry in exploration pits of the Batouri gold district, SE Cameroon. Journal of African Earth Sciences, v. 111, pp. 1-13.

Vishiti, A., Suh, C.E., Lehmann, B., Shemang, E.M., Ngome, N.L.J. Nshanji, J.N., Chinjo, F.E., Mongwe, O.Y., Egbe, A.J., and Petersen, S., 2017, Mineral chemistry, bulk rock geochemistry, and S-isotope signature of lode-gold mineralization in the Bétaré Oya gold district, south-east Cameroon. Geological Journal, https://doi.org/10.1002/gj.3093

Wambo, J.D.T., Ganno, S., Lahe, Y.S.D., Nono, G.D.K., Fossi, D.H., Tchouatcha, M.S., and Nzenti, J.P., 2018, Geostatistical and GIS analysis of the spatial variability of alluvial gold content in Ngoura-Colomines area, Eastern Cameroon: Implications for the exploration of primary gold deposit. Journal of African Earth Sciences, v. 142, pp. $138-157$.

White, S.R., 2001, Textural and microstructural evidence for semi-brittle flow in natural fault rocks with varied mica content. International Journal of Earth Sciences, v. 90, pp.14-27.

Wilkinson, J.J., 2001, Fluid inclusions in hydrothermal ore deposits.
Lithos, v. 55, pp. 229-272.

Woodcock, N.H., and Mort, K., 2008, Classification of fault breccias and related fault rocks. Geological Magazine, v. 145, pp. 435-440.

Yudovskaya, M.A., Distler, V.V., Chaplygin, I.V., Mokhov, A.V., Trubkin, N.V., and Gorbacheva, S.A., 2006, Gaseous transport and deposition of gold in magmatic fluid: evidence from the active Kudryavy volcano, Kurile Islands. Mineralium Deposita, v. 40, pp. 828-848.

Zhai, W., Sun, X., Sun, W., Su, L., He, X., and Wu, Y., 2009, Geology, geochemistry, and genesis of Axi: A Paleozoic low-sulfidation type epithermal gold deposit in Xinjiang, China. Ore Geology Reviews. v. 36, pp. 265-281.

Zoheir, B., Akawy, A., and Hassan, I., 2008, Role of fluid mixing and wallrock sulfidation in gold mineralization at the Semna mine area, central Eastern Desert of Egypt: evidence from hydrothermal alteration, fluid inclusion and stable isotope data. Ore Geology Review, v. 34, pp. 580596.

Zoheir, B., Emam, A., El-Amawy, M., and Abu-Alam, T., 2017, Auriferous shear zones in the central Allaqi-Heiani belt: Orogenic gold in post-accretionary structures, SE Egypt, Journal of African Earth Sciences, https://doi.org/10.1016/j.jafrearsci.2017.10.017.

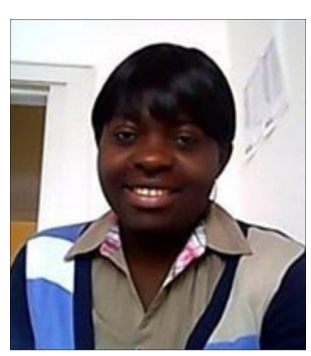

Akumbom Vishiti Ph.D is an Economic Geologist in The University Institute of Technology (IUT), University of Douala. Her main research interest includes ore processing and mining and the environment.

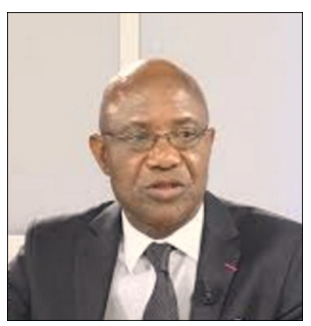

Jacques Etame is a Professor of Low temperature Geochemistry and the Director of The University Institute of Technology (IUT), University of Douala. He is currently working on projects with IRD.

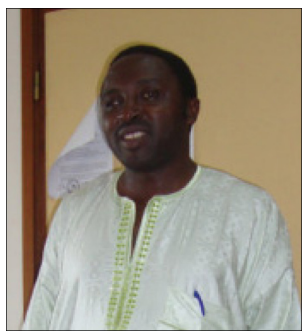

Cheo Emmanuel Suh is a Professor of Economic Geology and Microtectonics and a Humboldt Fellow. He is also a mining consultant in Cameroon and the Deputy ViceChancellor for Academic Affairs at The University of Bamenda. 